\title{
American Indian
}

National Cancer Institute

\section{Source}

National Cancer Institute. American Indian. NCI Thesaurus. Code C43877.

Denotes a person having origins in one of the indigenous peoples of North America, who lived on the continent prior to the European colonization. The term includes individuals belonging to a large number of tribes, states, and ethnic groups, many of them still enduring as communities. 